\title{
SCIENCE
}

\section{Transform Fault and Rift Valley from Bathyscaph and Diving Saucer}

Observations by earth scientists at the bottom of the sea shed new light on the geology of plate boundaries.

ARCYANA

\begin{abstract}
- The FAMOUS (French-American MidOcean Undersea Study) program was designed to conduct an integrated and detailed geological, geophysical, and geochemical study of a portion of plate boundary where new oceanic crust is generated and where some processes leading to the formation of the oceanic lithosphere may appear more clearly $(I)$. The originality of the program was to include the use, for the
\end{abstract}

ARCYANA is a collective name, based on the names of the submersibles Archimede and Cyona, for Jean Francheteau (geophysicist), Roger Hékinian (petrologist), Xavier Le Pichon (geophysicist), and David Needham (marine geologist), Centre Océanclogique de Bretagne, B.P. 337, 29273 Brest; Pierre Choukroune and Paul Tapponnier (structural geologists), Laboratoire de Géologie Structurale, Universite des Sciences et Techniques du Languedoc, Place Emile Bataillon. 34000 Montpellier; Gilbert Bellaiche (marine geolog1st), Laboratoire de Geologie Dynamique, Centre National de la Recherche Scientifique (CNRS). La Darse, 06230 Villefranche-sur-Mer; and Jean-Louis Cheminée (volcanologist), Laboratoire de Géologie Dynam
CNRS. 4 Place Jessieu, 75230 Pa ris-Cedex 05. first time, of precisely navigated, manned research submersibles in the latter phases of the work at sea and thus enable methods of classical field geology to be applied to the study of the deep ocean floor. Collection of data on a scale ranging from centimeters to kilometers was demanded by the narrowness of the surface expression of the plate boundary. -

The study area lies along the boundary between the North American and African plates, southwest of the Azores archipelago in an area where a segment of rif valley $40 \mathrm{~km}$ long, $30 \mathrm{~km}$ wide, and $1.5 \mathrm{~km}$ deep, oriented approximately $020^{\circ}$, is offset by two active fracture zones (transform faults) striking east-west. It had been demonstrated before the first dives were made that the deepest part of the rift valley or inner floor accommodates along part of its length an elongated hill or central high 200 $m$ high and $1 \mathrm{~km}$ wide (Fig. 1), and it was suggested that the central high, although not necessarily an entirely constructional feature, was the major locus of the most recent accretion of new surface crust (2). The purpose of the first diving phase, which was undertaken with the bathyscaph $A r$ chimede in 1973, was to test this hypothesis and to show that useful geological mapping from submersibles was possible even in the very rough terrain of the rift valley (3).

The second phase of diving was carried out in the summer of 1974 with Archimede and the diving saucer $C$ yana and had three main objectives. The first was to extend the 1973 survey in order to map and sample across the transition from features near the axis of the inner floor, which we knew to be at least partly attributable to primary volcanism, to the deepest features of the walls flanking the inner floor, which we presumed to be essentially of tectonic origin (box I, Figs. 1 and 2). This structural and petrological section of the inner floor of the rift valley was to be compared with a section investigated by the American team immediately to the south, in a location where no clearly developed central high was present.

Although transform faults are satisfactorily explained on kinematic grounds, their morphology and geology, which provide important constraints for ridge crest mechanical models, have not been adequately described. Therefore, the second objective of the dives was to study the median portion of transform fault $A$, which offsets the rift valley segment about 20 $\mathrm{km}$ in a dextral sense. There, according to magnetic anomalies (2), crust on either side of the valley should be about 1 million 
years old (box II, Figs. 1 and 2). The first purpose of the study, as of any structural study, was to define the geometry of the tectonic features - that is, to determine the spatial arrangement of faults. Second, it was hoped to determine where deformation is occurring at present, to work out the recent distribution of shear movement on the transform fault boundary, and to look for evidence of any additional extensional or compressional components of motion. This information would enable the width of the present surface expression of the transform boundary to be better defined, and help to establish whether the geometry has been stable through time. Finally, we needed samples from major fault scarps to investigate whether oceanic crust formed in the inner floor near a transform fault is petrologically peculiar, and we hoped that they would give direct proof of the nature of relative motion on the scarps.

The third objective was to map the intersection of the deepest part of the rift valley with transform fault A (box III, Figs. 1 and 2). The intersection between an accreting plate boundary and a transform fault is important in several ways. First, there is the tectonic problem of understanding how the domain in extension of the rift valley is linked to the domain in shear of the transform valley-that is, whether the transi- tion from rift to transform structures is abrupt or whether there are tectonic features of intermediate direction and nature reflecting a gradual transition. Second, the intersection area may provide, for both domains, an insight into the width of the zones in which the greater part of the motions is localized. Finally, a study of the intersection, where crust of greatly different ages is juxtaposed, may show how crust of varying age responds to tectonic forces.

We used as a base for the dives a precise and detailed bathymetric map based on a narrow-beam survey by the French Hydrographic Office ship d'Entrecasteaux (4). In 1973 Archimède made 6 successful dives.

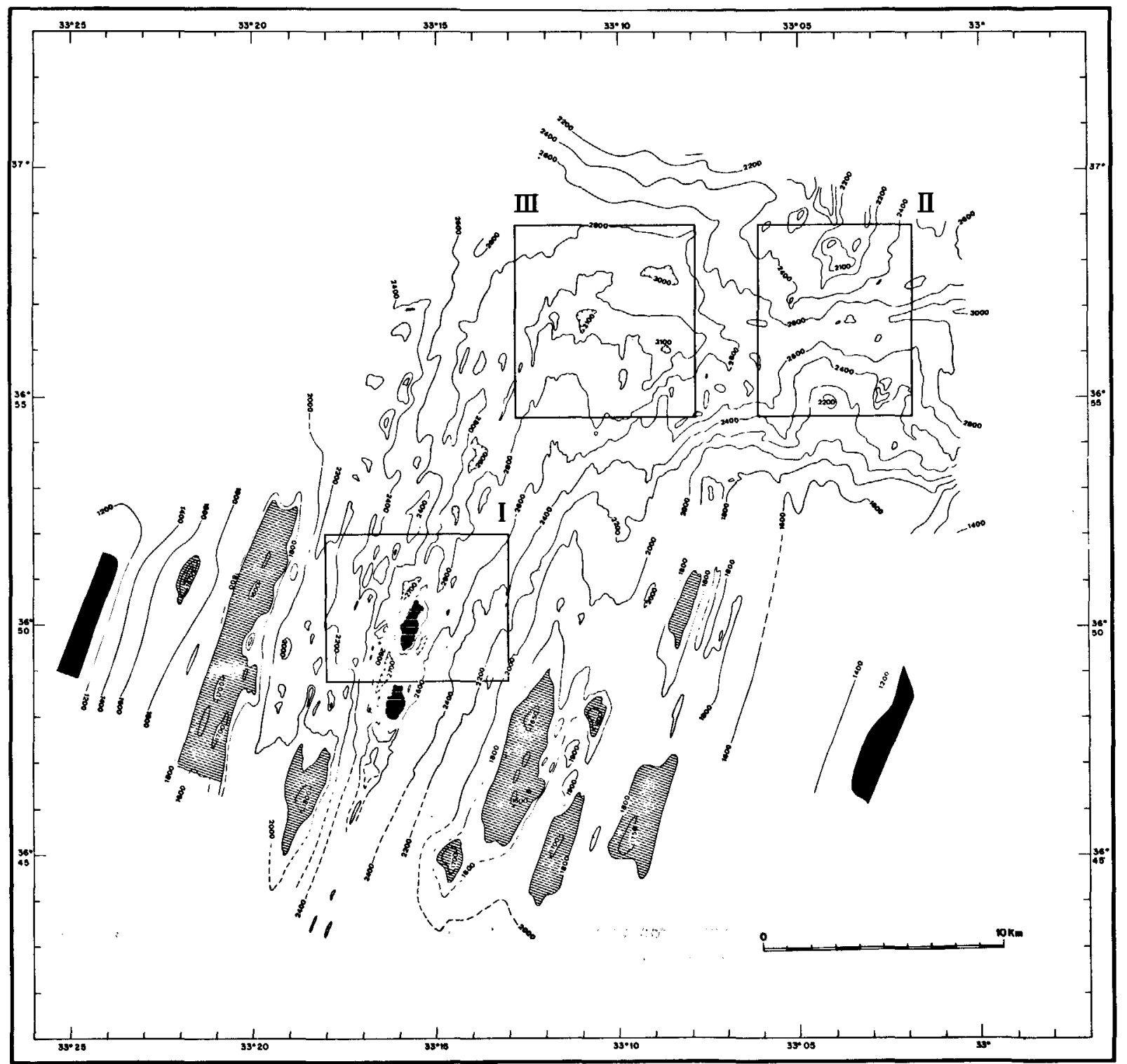

Fig. 1. Bathymetry of parts of the rift valley and transform fault A. Submersible dives were conducted in regions I, II, and III (see Fig. 2). The axis of transform fault $\mathrm{A}$ runs approximately east-west along $36^{\circ} 57^{\prime} \mathrm{N}$. The black areas mark the edges of the rift valley. Ruled areas represent topographic highs on the inner walls of the rift valley. In the inner floor, black areas with horizontal white stripes show the location of Mont de Venus (in box I) and Mount Pluto (south of box I). Contours are given in corrected meters, after Needham and Francheteau (2) and the d'Entrecasteaux survey (4). 
and in 1974 Archimede and Cyana each made 12. Out of the total of 30 dives, 15 were made in the first zone (rift valley, box I, Figs. 1 and 2), 10 in the second zone (transform fault, box II, Figs. 1 and 2), and $S$ in the third zone (intersection, box III, Figs. 1 and 2). The dives represent a total of $50 \mathrm{~km}$ of visual coverage of the sea floor with a precision of navigation of about 20 $m$ relative to the acoustic bottom-transponder network, which was associated with the d'Entrecasteaux survey. Eighty-five rock and sediment samples were collected. About 10,000 photographs and 50 hours of videotaped television coverage were obtained, together with color photographs and movies.
This article is based primarily on shipboard evaluation of data. It does not include results of detailed (structural or petrological) analyses or of age determinations of the samples. Our conclusions, which have not yet been compared with the conclusions reached by our American colleagues on the complementary part of the program, should be considered as preliminary. It is worth stressing that any observation made on the sea floor provides information on the superficial state of the crust at a given place, and at a given time in a long evolution. It is hoped that the geographic coverage gives, besides the spatial integration, information on other phases of the evolution in time.

\section{Rift Valley}

The rift valley, with a maximum depth below sea level of $2.8 \mathrm{~km}$, is composed of a series of large steps, typically with an outward tilt (2) and separated by steep slopes facing toward the axis of maximum depth. The axial zone can be very narrow, but in the area of the dives it is marked by a 3$\mathbf{k m}$-wide, topographically rough inner floor $(2,5)$ incorporating three highs with narrow bordering deeps. The central high, which in this area is called Mont de Vénus (3), is about $4 \mathrm{~km}$ long and $1 \mathrm{~km}$ wide and stands about $250 \mathrm{~m}$ above the flanking deeps. The wall bordering the inner floor on the western side is higher, regionally
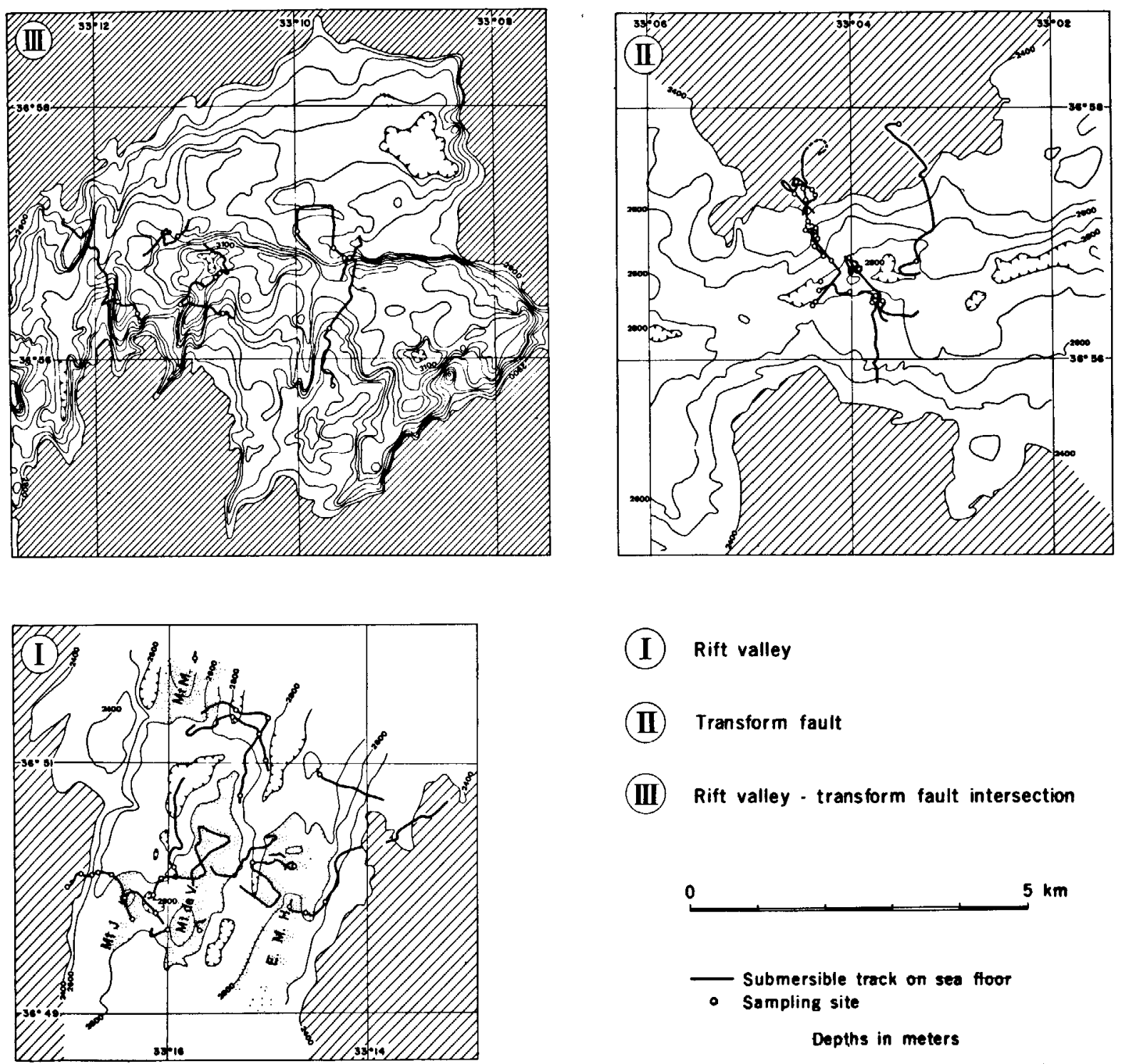

(I) Rift valley

(II) Transform fault

(III) Rift valley - transform fault intersection

0 $5 \mathrm{~km}$

Fig. 2. Bathymetry from the $d^{\prime}$ Entrecasteaux survey (4) in three dive regions showing submersible tracks on the sea floor and sampling sites. In box $I$ prominent topographic highs are stippled: Mt. de V.. Mont de Vénus; Mt. J.. Mont Jupiter: Mt. M, Mont Mercure; E.M.H., eastern marginal high. In boxes I and II, sea floor above $2400 \mathrm{~m}$ is shaded. In box III, sea floor above $2900 \mathrm{~m}$ is shaded. The contour interval is $100 \mathrm{~m}$ (corrected) in boxes I and II and $20 \mathrm{~m}$ in box III where the topography is relatively smooth. 
steeper, and better defined for long distances along strike than the eastern wall ( 2 . 5).

Of the 15 dives conducted in the rift valley by the French submersibles, 3 were made on the deep lower scarps and steps of the eastern wall, I was on the prominent scarp flanking the inner floor on the west, and the others were devoted to the various formations of the inner floor (box I, Fig. 2).

Inner floor. The 1973 Archimède dives led to the definition of various specific associations of lava morphologies and structural settings. Globular forms, sometimes collapsed, and pahoehoe-type lavas were found on the flattish, upper parts of flows, and "bolsters" were found on steep fronts of flow units. Talus made up of broken, radially jointed rocks were shown to be associated with the feet of steep scarps.

The $\mathbf{1 9 7 3}$ dives also showed that surface emplacement of new oceanic crust is achieved in the inner floor and that, at least at the surface of the crust, the zone of magma injection is limited to volcanoes built by thick, steep-fronted piles of pillow lavas. It was concluded that these are built over relaying fissures within a zone 0.5 to I $\mathrm{km}$ wide. Evidence of tectonic activity was found on the inward-facing slope of the eastern marginal high.

The four rocks sampled in 1973 by $A r$ chimede show an increase in age with distance from Mont de Vénus, which would thus mark the locus of the most recent volcanic activity $(<10,000$ years) $(3,6)$. Three of the rocks, all sampled within a distance of $2 \mathrm{~km}$ in a direction transverse to the rift, were of different petrographic types (pyroxene basalt, olivine basalt, and picritic basalt) (3.7). This reflects a lateral and vertical variation in petrology linked tightly to structural setting. and further refines knowledge of the across-strike variation of rock types in the deeper part of the rift valley, previously recognized from the relative abundances of large plagioclase and olivine crystals (2).

The 1974 Archimède and Cyana dives considerably extended the geological reconnaissance over the whole inner floor toward both east and west, and included the study of scarps and slopes of tectonic origin and of steps which bound the inner floor and form the bases of the walls of the rift valley. In the axial part of the inner floor two structural modes dominate: the emissive and the tectonic.

The emissive mode is exemplified by Mont de Vénus, where recent volcanic flows, probably fed by emissive fissures. mask tectonic structures. Progression of lava flows is shown by bolsters of various sizes giving way to pillows, pahoehoe-type lavas, and "tripe" (3). Most of the differ- ent volcanic forms are created in successive phases. For example, the molten lava is quenched upon extrusion at the surface. yielding a glassy crust which can be cracked. The lava in the interior is pushed through the cracks as in a drawplate, producing grooves. Frequently, slabs of the glassy crust of globules or bolsters are upheaved, creating relief in the shape of mushrooms or berlingots (2). The 1974 dives confirmed that the tops of the flows are formed principally of large lava globules ("skeins of yarn") and elongated pillows (3). In addition, lava sheets and ropy lava were observed on the northern part of Mont de Vénus.

The tectonic mode is represented, to the north, northeast, and southwest of Mont de Vénus, by fields of open fissures (or gias) oriented parallel to the rift valley trend. Some of the gjas have clearly disrupted the volcanic edifices in the northnortheastern part of Mont de Vénus, and on the western slope of the topographic high which represents the northern prolongation of Mont de Vénus.

Both the tectonic (or extensive opening) mode and the emissive mode of the axial part of the inner floor give way laterally, with an additional component of vertical relative motion, to a horst and graben structure. The horst discovered in the eastern part of the inner floor, the eastern mar ginal high, is bounded to the east by an eastward-facing normal fault, but coherent lava flows are observed on part of its rectilinear, partially faulted western flank. This last observation suggests that the high is a relatively recent emissive center and is evidence of post-tectonic or syntectonic volcanism. The horst observed to the west, the western marginal high at $36^{\circ} 50^{\prime} \mathrm{N}$, which we call Mont Jupiter, is more heavily fractured and faulted than its eastern counterpart. In addition to the structures following the $020^{\circ}$ rift valley trend, which include here important open fissures, transverse faults and gjas oriented $080^{\circ}$ are apparent This intersectung set of structures is responsible for the existence of jagged peaks not found elsewhere. In particular, none of these transverse structures were observed on the eastern side of Mont de Vénus. The graben that lie between the marginal horsts and the base of the walls have sedimentcovered floors about $100 \mathrm{~m}$ wide.

Borders of the inner floor. The lower part of the eastern wall, which is made up of three main steps below $2100 \mathrm{~m}$, is apparently older than the inner floor, although it is not yet clear whether ages increase linearly with distance from the axis of the inner floor. Although well-preserved lava flows were observed on the walls, they are more weathered, and bottom life is richer here and sediment cover thicker. The faulted scarps of the lower part of the eastern wall (one fault about every $50 \mathrm{~m}$ ) have bare lava talus at their feet; together with the fresh appearance of the scarps themselves. this indicates that the lower part of the wall is still tectonically active, as may be inferred from a microearthquake survey further south ( 8 ).

A complete traverse of the well-defined western wall, west of Mont Jupiter, was made during one dive of Cyana (Fig. 3). Morphologically, the surface of the wall appears as a series of vertical scarps 10 to $20 \mathrm{~m}$ high, separated by shorter, less steep slopes. The base of the wall is hidden under a talus pile made up of pillow fragments and large angular blocks ( 1 to $2 \mathrm{~m}$ in diameter). The talus, which is more than $85 \mathrm{~m}$ high, abuts against a unit of breccla $50 \mathrm{~m}$ thick. The lower part of the breccia is made up principally of sediment, whereas the upper part is predominantly rocky and is crossed by dikes. The breccia unit is overlain by a $230-m$-thick pillow lava pile incorporating several dikes (oriented $020^{\circ}$ ) and sills, particularly in the lower part. The sills are conformable subhorizontal igneous units about $1 \mathrm{~m}$ thick, which show no glassy layer at their contact with the overlying extrusives. The top of the first major step of the west wall has a horst and graben structure parallel to the trend of the wall. It is tempting to equate the pillow lava pile with the magnetized layer $2 \mathrm{~A}$

Rocks. A total of 27 rock samples from 25 stations has now been collected from the inner floor of the rift valley, the marginal highs, and the lowermost scarps of the eastern and western walls (box I, Fig. 2). Most of the specimens come from the flanks of Mont de Vénus, Mont Jupiter. the marginal high to the north of Mont Jupiter, which we have called Mont Mercure, and from the eastern marginal high. The freshest specimens were collected from Mont Mercure and Mont de Vénus.

The specimens from the inner floor occur typically as radially jointed pillow lava fragments with glassy margins coated with thin palagonite and manganese tilms. The specimens are all basalts and the great majority are enriched in olivine with occasional chrome spinel. The basalts that have olivine as the major phase are divided into olivine and picritic basalts. the latter containing up to 30 percent olivine megacrysts and found typically at the base of Mont de Vénus. The other two most abundant basalt types found in the inner floor are moderately phyric plagloclase basalts containing plagioclase phenocrysts, olivine, and clinopyroxene as major constituents, and basalts relatively rich in clinopyroxene and olivine. The former are 


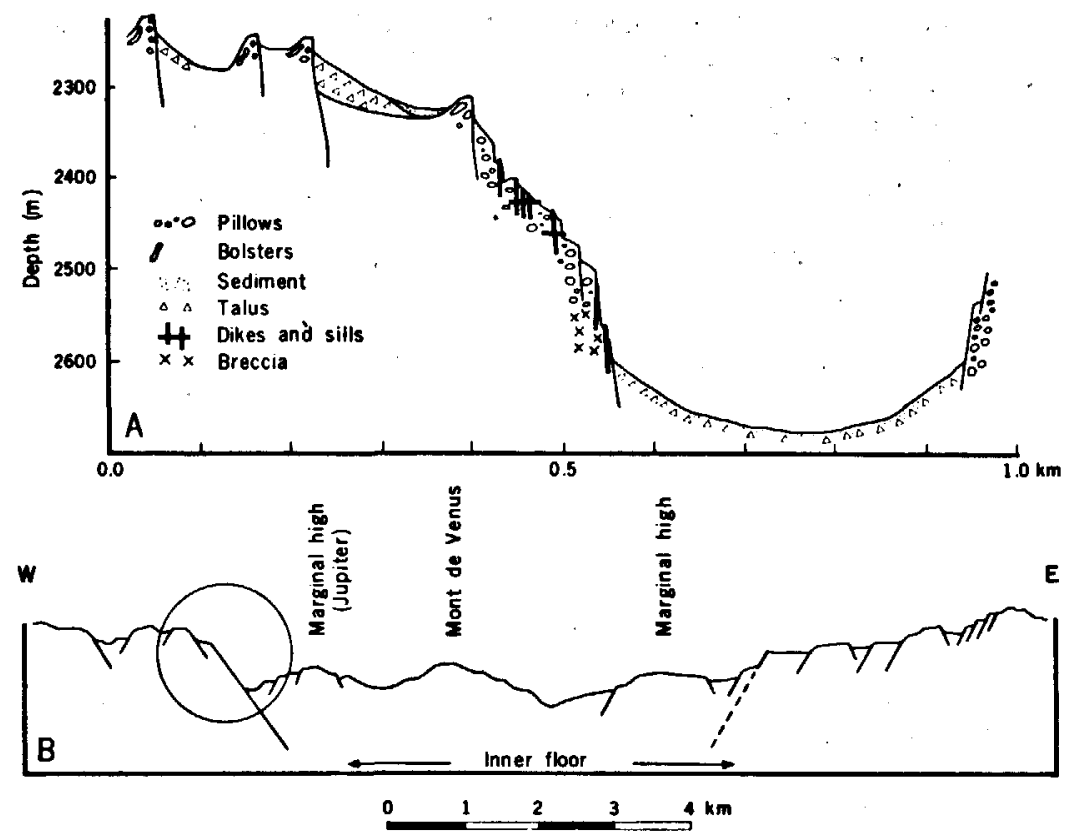

Fig. 3. (A) Sketch showing surface geology observed during one dive of Cyane up the western scarp bounding the inner foor, west of Mont Jupiter. Fault extension at depth is hypothetical. The bathymetry is derived from dive data. (B) Profile drawn from d'Entrecasteaux survey (4), showing the setting of the Cyana profile (circle). Both profiles are drawn with no vertical exaggeration.

similar to the high-alumina basalts described from other parts of the rift valley in the Atlantic (9).

Highly phyric plagioclase basalts were found along the western scarp bordering the inner floor. These rocks differ from the moderately phyric plagioclase basalts in that the plagioclase crystals are more calcic ( $>20$ percent) and show evidence of resorption. The megacrysts in the highly phyric plagioclase basalts are set in a ground-mass which consists essentially of clinopyroxene.

The rarest type of rock sampled during the dives is a pyroxene-rich basalt with clinopyroxene and plagioclase as major constituents, the clinopyroxene content being equal to, or higher than, the plagioclase content. One such specimen comes from high on the western scarp itself, which is clearly tectonic, and there is field evidence that the rock sampled may represent an intrusion injected into the scarp.

Discussion. The dives in the rift valley have shown that there are rapid variations in structural style and petrographic type across the inner floor and bounding tectonic walls. Tectonic and volcanic phases can follow one another, with concomitant variations in the chemistry of the lavas both along and across the strike of the main structures. The mode of extension of the crust is principally by dikes and open or emissive fissures in the 1- to $2 \cdot \mathrm{km}$-wide axial part of the inner floor, and by normal faults in the walls. In the axial part of the
Mont de Vénus is the youngest volcanic edifice in a section across it (6).

It is tempting to put the present plate boundary along the central high (Mont de Vénus), although it is clear that the present zone of active extension by normal faulting in the rift valley is wider than the present zone of magma extrusion. It extends over a half-width of at least $\mathbf{4 k m}$, on the basis of the dives made on the lower part of the eastern wall.

The plate boundary must lie within the tectonically active zone, which is a zone of mechanical weakness fractured in response to the divergence of the plates. It does not necessarily coincide with the axial region of the inner floor, although active volcanism, which is responsible for forming oceanic crust, occurs only in the region where fractures are deep enough to tap the underlying magma, and most of the extension takes place in the axial region. Careful dating of the rocks sampled will support this relationship if it shows a monotonic increase in age with distance from the axis.

It seems likely that normal faults affect the crust both inside $(8)$ and outside the rift valley in areas not covered by the dives. Even on the evidence we have, it is clear that the strongly faulted nature of the oceanic crust, at least in an area of slow spreading, dictates that great care be exercised when interpreting results from nearvertical drill holes in the crust of the type made during Deep Sea Drilling Project (DSDP) leg $37(10)$. The density of faulting in the active tectonic zone shows that nearvertical holes, which are on the average $300 \mathrm{~m}$ deep in the crust, should encounter at least three fault zones and probably more. Much of the rubble encountered in the holes $(10)$ may be associated with the faults. In any case, it does not seem possible to arrive at a true representation of the igneous stratigraphy of the oceanic crust until motions along the faults are taken into account. Along the scarps of the rift valley walls one can observe a section through the upper part of the oceanic crust which may be as thick as $500 \mathrm{~m}$, which is similar to the depth in the crust reached during DSDP leg 37. The horizontal continuity of the western scarp section, over kilometers, should be helpful for interpreting the significance of vertical borings. Because the FAMOUS program was devoted mostly to the study of the extension within the inner floor, a study by submersibles of rift valley walls seems a high-priority target for the future, in connection with the International Phase of Ocean Drilling (IPOD) plans to drill through the upper part of the oceanic crust. Field mapping and deep coring are both essential tools for understanding the geology of tectonically complex areas. 


\section{Median Transform Fault Zone}

A transform fault, which corresponds to the active portion of a fracture zone $(I I)$, is a class of fault introduced by Wilson (I2) primarily on kinematic grounds. The term is usually applied to a portion of crust where active pure shear prevails, connecting two regions where crust is generated or destroyed. A new terminology, borrowed from the earthquake fracture literature (13), seems to be required for a more detailed description of the surface morphology and structures of transform faults. Morphologically the transform faults, at least in the Atlantic Ocean, are defined by valleys which we call transform valleys. Within a transform valley the area where most of the active tectonic features occur is called a transform fault zone. It is conceivable that, when followed through time, a transform fault zone may migrate in a direction parallel to the rift. We use the term transform domain to include all locations occupred by a given transform fault zone throughout its evolution in time. If a single narrow zone accounts for the major part of the ground movement in the transform fault zone, it is termed the principal transform displacement zone, and it may itself be composed of transform shear zones.

Structure. The east-west transform fault A offsets the rift valley about $20 \mathrm{~km}$ in a dextral sense, and the motion in the transform fault zone should thus theoretically be sinistral. The area we explored lies around $36^{\circ} 56^{\prime} \mathrm{N}, 33^{\circ} 04^{\prime} \mathrm{W}$, about midway between the two offset segments of rift valley. Assuming a spreading rate of 1 $\mathrm{cm} /$ year $(2,14)$, crust on opposite sides of the transform fault zone should be about I million years old. A $2.5-\mathrm{km}$-long, northsouth section across the axial region of the transform valley was covered in the course of ten dives. Parts of the transform fault zone were mapped in detail, the study including microtectonic observations.

The deepest axial region of the transform valley is V-shaped and is characterized by relatively steep slopes, giving way to slopes with smaller average gradients (Fig. 4). In the external portions of the transform valley, to both north and south, another break in slope and large escarpments more than $100 \mathrm{~m}$ high constitute the limit of the transform domain, which has an average width of about $3 \mathrm{~km}$ and a total vertical relief of $600 \mathrm{~m}$. The observed morphology of the transform valley slopes is the expression of brittle tectonic deformations, which have affected the whole of the transform domain. For example, the sea floor topography is marked by a series of east-west trending steps and scarps, with the height of the scarps varying from 50 $\mathrm{cm}$ to several tens of meters and the spacing between them varying from several meters to several tens of meters. The appearance of the scarps, which are sometime smoothed by a sediment cover, made it possible to distinguish fossil tectonic zones from zones presently active, and thus to distinguish the transform fault zone within the transform domain.

In the zone of intense fracturing, tectonic observations conducted on the seabed permit localization of the zone where the movement is concentrated at present. The transform fault zone incorporates the first (deepest) steps of the flanking walls of the transform valley, and its width is thus less than $\mathbf{l} \mathbf{~ k m}$. Microtectonic observations were made on deformed sediments affected by cleavage on scarps striking roughly east-west on the south wall of the transform fault zone. The angular relation between fault and cleavage planes is direct evidence of the existence of shear displacement and of a left-lateral sense of movement.
On either side of the deep active region, gentler topographic features and sedimented scarps suggest the existence of fossil tectonic structures. Beyond and above this presently inactive region, which we include in the transform domain, another active tectonic zone corresponds to the outer escarpment of the north flank of the transform domain. The presence of striations, with a $45^{\circ}$ pitch to the horizontal of the approximately east-west plane of motion, on indurated sediments affected by cleavage shows that, on the outer escarpment, the vertical component of motion is important. This contrasts with the predominantly horizontal motion in the deep inner zone.

Most of the steep scarps within the transform fault zone are made up of more or less consolidated detrital material, which is continually remobilized by tectonic activity. Sediment cover is abundant on the south fiank of the transform valley as well as on all flattish areas and on the bottom of the valley. The outer portions of the transform domain, where the slopes are smaller, are covered by thicker sediments and there are some outcrops of pillow lava flows. Approximately east-west trending dikes, which appear as near-vertical walls up to $16 \mathrm{~m}$ high, $10 \mathrm{~m}$ long, and 1 to $2 \mathrm{~m}$ thick, were observed frequently, especially on the northern flank of the transform valley. The dike walls are either massive or made up entirely of breccias and appear to have a foliation parallel to their strike.

Banded or massive dolerites constitute the greater part of the rocks of the outer northern escarpment. This material may have been exposed by the vertical component of motion on the scarp or it may represent intrusives (sills) associated with the fault scarp. Dikes of the same material were observed at the base of the break in slope. The rock section exposed on this fault scarp with a dip-slip component is

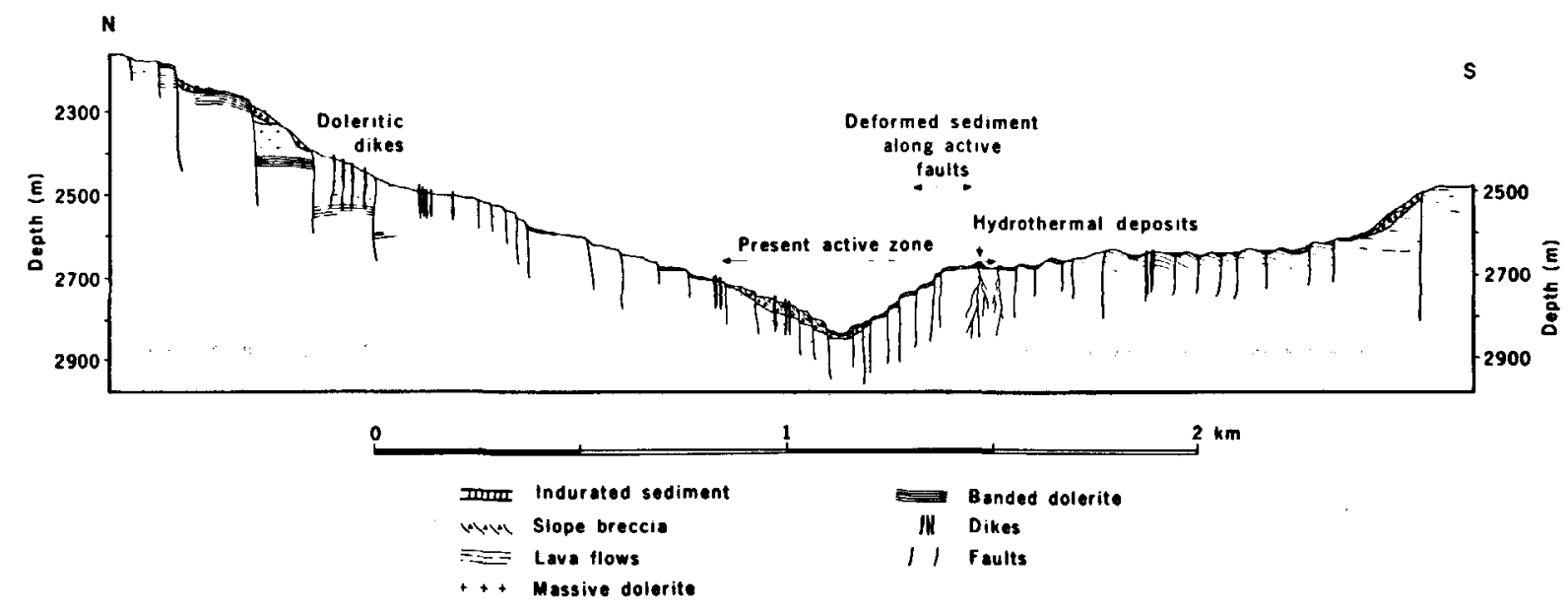

Fig. 4. Schematic diagram incorporating main geological and tectonic observations in median part of transform fault A (see box II, Fig. 2, for location). The profile is drawn with no vertical exaggeration. 
thus different from the section observed on the western scarp of the inner floor of the rift valley, west of Mont de Vénus.

Rocks. The 25 rock samples collected from the north and south walls of the transform valley are mainly pyroxene-enriched. The major constituents of these rocks are clinopyroxene, plagioclase, and iron oxide minerals. Other samples, collected near the northeasternmost portion of the dive area and the deepest part of the transform valley, contain olivine in addition to plagioclase and clinopyroxene. Many of the rocks are very weathered and hydrothermally altered and have relatively thick encrustations of manganese and iron hydroxide. The rocks sampled on the northern escarpment are more deeply altered and contain hydrous minerals such as smectite and chlorite in addition to hematite. The rocks have no glassy margins and are holocrystalline with ophitic, subophitic, and intersertal texture. Field evidence accompanied by the textural appearance of the rocks indicates that the pyroxene-enriched rocks from the northern margin of the transform domain are intrusives. Two specimens of volcanic breccia were collected close to a depth of $2500 \mathrm{~m}$, about $1 \mathrm{~km}$ north of the deepest part of the transform valley, in the region where numerous dikes were seen.

Hydrothermal deposits. The dives in the median portion of transform fault A led to the first in situ observation and sampling on the deep sea floor of colored deposits of evidently hydrothermal origin, and to the first observation of the mouths of the hydrothermal sources.

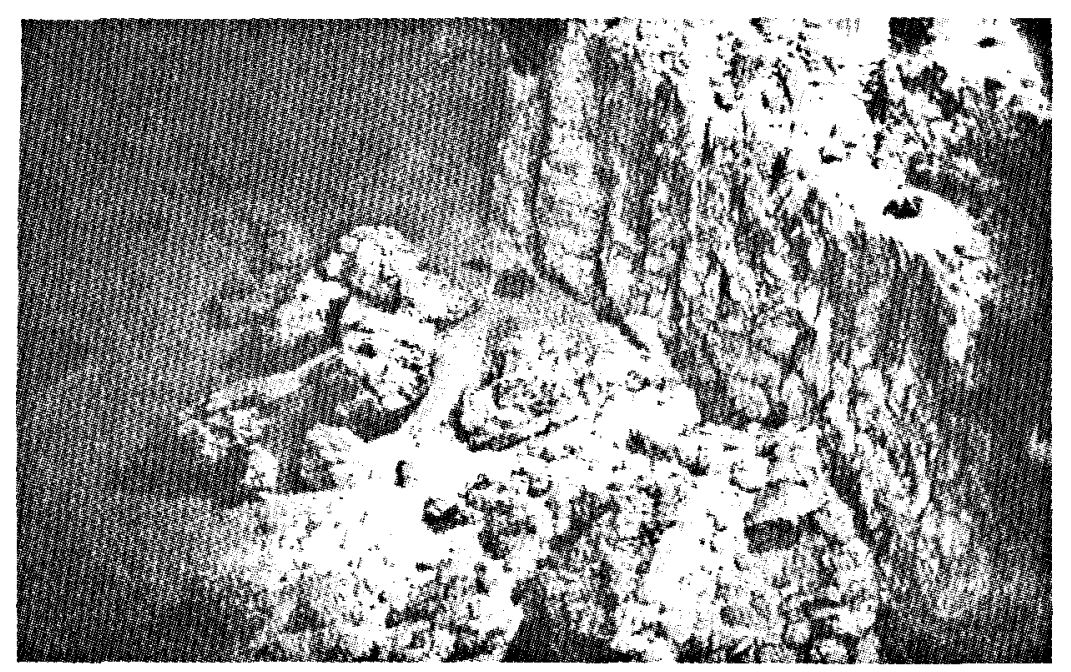

Fig. 5. Fault scarp associated with the left-lateral shear of transform fault $A$. The fault, about $150 \mathrm{~m}$ north of the major east-west escarpment, cuts through indurated sediments with clear subhorizontal bedding marked by blacker material. The view into the picture is along $185^{\circ}$. The scarp, which is about $1.5 \mathrm{~m}$ high, has a strike of about $150^{\circ}$ to $330^{\circ}$. Cleavage indicates that motion on the scarp is left-lateral. Blocks of indurated sediment with big cavities are covered by manganese. The hole at the base of the scarp was made while coring with the telemanipulated arm of Archimede.
Two neighboring hydrothermal deposits. about $100 \mathrm{~m}$ apart, were discovered toward the top of the scarp which forms the southern limit of the deep portion of the transform valley (Fig. 4). Both cover an area of about 40 by $15 \mathrm{~m}$ and are emplaced on hills which are elongated in the eastwest direction and which have steeper north-facing than south-facing slopes. The hills are capped by stratified deposits and black, scoracious-like encrustations lying on sediment. The deposits are typically 10 to $50 \mathrm{~cm}$ thick, but can reach a thickness of about $1 \mathrm{~m}$ next to the emissive vents or fissures. The vents are located at the summit of, or relatively high on, the north-facing slope of the hydrothermal hills. Both of the observed hydrothermal vents are elongated in the east-west direction. Downhill from the vents, black travertine-like deposits carpet the slope. whereas red, yellow, or green pisolitic forms lie close to the vents. The rounded pisolitic forms have a concentric zonation, dark green in the center to red and black in the outer layers. Preliminary analyses ( 15 ) show that the samples are mainly iron-manganese deposits depleted in all other transition elements $(\mathrm{Co}, \mathrm{Ni}$, and $\mathrm{Cu}$ contents are less than 10 to 15 parts per million). The $\mathrm{Fe} / \mathrm{Mn}$ ratio shows a large variation $(0.2$ to 237$)$ and there is evidence that the iron-rich deposits were precipitated close to the vents and the manganese-rich crusts farther from the points of thermal water discharge. The field evidence supports models presented by Bonatti and co-workers (16) for deposits of analogous chemistry in northern Afar and in the Mediterranean Sea.
The location of the hydrothermal deposits in the presently active tectonic zone may not be fortuitous. The transform fault zone, which is the seat of presumably deep vertical fractures that have been active for a long time and involve a high level of shearing and microfracturing, is a particularly suitable setting for fluid circulation and efficient leaching of crustal rocks by hot seawater. No hydrothermal deposits were observed in the $\mathbf{3 0}$ dives by Alvin and the two French submersibles in the active rift zone, where faults are not vertical, may not extend as deep, and may not be active for such a long time. However, we cannot preclude the possibility that hydrothermal deposits in the rift valley are masked by lava in the axial volcanic zone and by the large talus deposits along bordering scarps.

Discussion. The series of dives in the median part of transform fault $\mathbf{A}$ has shown that the presently active transform fault zone, straddling the deepest part of the transform valley, is about $1 \mathrm{~km}$ wide. The transform domain, in which the active elements of the tectonic system are located at various times throughout its evolution, is about $3 \mathrm{~km}$ wide. Field observations show that left-lateral shear with little contribution from dip-slip prevails in the transform domain, but that dip-slip becomes significant above it. At least locally within the transform domain there is evidence of shortening.

The observation, on the walls of the transform valley, of weathered extrusives (about 1 million years old, judged by the thickness of manganese oxides on the rock surfaces), which were probably emplaced at the neighboring accreting boundaries, and the small vertical extent of the largest scarps show that the commonly accepted concept that a $1-\mathbf{k}$ m-deep transform fault is equivalent to a $1-\mathbf{k m}$-high fault is unrealistic. The structural setting of ultramafic rocks within transform valleys remains unclear because no such rocks were recovered during the dives. However, many of the reported occurrences of mafic or ultramafic material in transform faults may represent intrusives associated with faults, such as the dolerites sampled on the outer scarp of the transform domain. Models of transform fault petrology displaying vertical zonation with peridotite and serpentinite overlain by gabbro, itself covered by basalts, are rendered questionable.

Finally, proof has been gathered that mineral concentrations which cannot be explained by surface authigenism occur on newly formed oceanic crust. They are presumed to be the result of precipitation in cold seawater from hot water enriched by leaching of crustal rocks in a zone with intense microfracturing. Transform fault zones inay represent preferred locations 
for mineral enrichment. Previous detailed work from a surface ship, including the use of near-bottom instruments (50 to 100 $m$ above the sea floor) had failed to provide evidence for the presence of the hydrothermal deposits.

\section{Rift Valley-Transform Valley}

\section{Intersection}

The intersection of the rift valley and transform fault $A$ is expressed topographically by a large, roughly circular depression about 300 to $400 \mathrm{~m}$ deep with a radius of about $3.5 \mathrm{~km}$ (box III, Figs. 1 and 2). The floors of both the rift valley and the transform valley deepen toward the intersection, and the maximum depth of the intersection region (>3000 m) thus represents the greatest depth found along the plate boundary. The transform valley in the intersection area includes, in its axial portion, a trough $7.5 \mathrm{~km}$ wide bordered by steep, inward-facing scarps 300 to $400 \mathrm{~m}$ high. This trough, which is analogous to the $3-\mathrm{km}$-wide transform domain in the median part of transform fault $A$, is cut by a seismically active axial deep $1 \mathrm{~km}$ wide, flanked on the north side by a prominent south-facing near-vertical scarp or wall, strikıng east-west along $36^{\circ} 57^{\prime} \mathbf{N}$, and about 100 to $130 \mathrm{~m}$ high (17).

Five dives of Archimede were conducted in the general area of the intersection (box III. Figs. I and 2). The two easternmost ones were devoted to the study of the major east-west scarp, and the three others were closer to the intersection where the transform fault should juxtapose approximately 2-million-year-old crust (on the north side) and newly created crust (on the south side). Of the latter three, a short dive, just west of $33^{\circ} 11^{\prime} \mathrm{W}$, covered the western termination of the east-west scarp; one dive included traverses of the basin near $36^{\circ} 56.5^{\prime} \mathrm{N}, 33^{\circ} 11^{\prime} \mathrm{W}$, which is more than $3100 \mathrm{~m}$ deep; and one dive, the westernmost, was made across the trough near $33^{\circ} 12^{\prime} \mathrm{W}$ which trends in an intermediate $\left(045^{\circ}\right)$ direction.

Transition area. From the information provided by the narrow-beam bathymetric survey, the rift valley floor could be thought to lead into the intersection area either directly through a series of right-lateral, en echelon segments oriented roughly north-south or transitionally through the trough trending approximately $045^{\circ}$. Observations made near $33^{\circ} 12^{\prime} \mathrm{W}$ (box III, Fig. 2) showed the latter interpretation to be correct. An emissive fissure and wellpreserved flows, pillows, and bolsters similar to those found in the inner floor sites farther south were encountered along the l-km-long section traversed. The emissive fissure lies in sediment-covered terrain and is associated with a line of holes in the sediment. Both the fissure and the line of holes strike $045^{\circ}$, as does a series of sedimentary ridges and small faults approximately $2 \mathrm{~m}$ high associated with the bolsters. Most of the terrain seen is covered by sediment, even the fairly large scarps, and rock outcrops are found only in the $1-\mathrm{km}$-wide axial region and at the summit of some fault blocks in the south. Horsts and graben occur in the outer portions of the axial re gion, and most of them are covered with sediment. At the southern extremity of the dive profile, there is a large north-northwest facing scarp which strikes $065^{\circ}$, paralleling the main transform fault direction to a greater extent than do structures found in the axial region of the $045^{\circ}$ trough. This may indicate a greater component of extension in the latter area. In further contrast, the tectonic scarps and sedımentary ridges north of the axial region strike $010^{\circ}$ to $020^{\circ}$ and are thus more nearly paralle to the main rift valley trend. The geometry may indicate that termination of shear in the transform valley is rather abrupt and that shear probably extends less than 0.5 $\mathrm{km}$ beyond the $045^{\circ}$-trending trough. A different tectonic behavior is expected in the minor and major angles between the accreting and transform plate boundaries, in that superposition of tectonic regimes is more likely to occur in the minor angle where, in addition, crust is uniformly young.

During the dive across the termination of the major east-west wall around $33^{\circ} 11^{\prime} \mathrm{W}$, scarps with a strike of $070^{\circ}$ and exposing pillow lavas were seen to cut through smooth, flattish, sediment-covered areas. $A$ shear zone composed of apparent left-lateral, en echelon scarp segments up to $20 \mathrm{~m}$ high marks the termination of the east-west wall. The trend of the scarps fits with that predicted for Riedel synthetic shears, but no obvious tension features were observed connecting the scarps. The termination of the wall occurs about 1.5 $\mathrm{km}$ east of the last north-south striking segment of the accreting boundary.

The results of the two dives are compatible with the existence of a narrow zone (1 to $1.5 \mathrm{~km}$ wide) where most of the extension is now taking place. This is narrower than the width estimated from information obtained on dives to the inner floor sites to the south and may show that the greatest density of dikes and fissures (open or not) is to be found in the axial zone of the inner floor. Here, unfortunately, volcanic flows generally conceal this information. Similarly, the termination of the north-south accreting segment about $1 \mathrm{~km}$ south of the east-west scarp may indicate that the transform fault zone is roughly $1 \mathrm{~km}$ wide in this area. This result is in general agreement with direct evidence gathered farther east (box III, Fig. 2) and in the median portion of transform fault A (box II, Fig. 2).

The dive across the deep basin near $36^{\circ} 56.5^{\prime} \mathrm{N} .33^{\circ} 11^{\prime} \mathrm{W}$ (box III, Fig. 2) shows that the transform fault zone extends about $1 \mathrm{~km}$ south of the east-west wall and includes sinkhole-like depressions within a sedimentary terrain crossed by many sedimentary ridges. Rock exposures are rare and limited to tops of steps and some steep scarps. Apparently active scarps trending $045^{\circ}$. and exposing banded. massive rocks with bare talus piles at their bases, were followed about $2 \mathrm{~km}$ east of the northsouth accreting segment. The scarps may represent structures generated in the $045^{\circ}$ axial trough to the west or may be evidence that the transition between rift and transform structures is gradual and occurs over a wide region (18). The dimension of the transitional zone probably reflects both the thicknesses of the brittle portions of the crust and the width of both active boundaries.

East-west wall. A section across the east-west wall just east of $33^{\circ} 10^{\prime} \mathrm{W}$ shows that the wall is $130 \mathrm{~m}$ high and is made up of a series of sediment-covered steps separated by steep scarps. There are exposures of pillow lava piles and more massive lava on parts of the wall and of intrusives including doleritic dikes on other parts; in one instance, a $0.5-\mathrm{m}$-thick sediment layer was seen sandwiched between two pillow lava units. The linearity, continuity, and average east-west trend of the wall imply that it is the site of active shear. In this area it may represent the principal transform displacement zone. In detail, the scarp segments of the wall trend $070^{\circ}$ to $080^{\circ}$ and may correspond to synthetic shears associated with left-lateral motion.

Tectonic activity is not confined to the wall. About $150 \mathrm{~m}$ north of the east-west wall a recent fault. in close contact with a field of manganese oxide deposits lying on indurated sediments (Fig. 5), cuts through indurated sediments which may be affected by cleavage. and an emissive fissure trending $045^{\circ}$ is located, within the sedimentary terrain, about $300 \mathrm{~m}$ north of the edge of the wall. This, incidentally, represents the only clear case of recent volcanism seen within the transform fault zone. The strike of the emissive fissure, a tension fracture, is compatible with the left-lateral direction of movement in the transform fault. A few tens of meters north of the wall, there is a large ( 5 by $3 \mathrm{~m}$ ), oval, east-west trending doline-like depression, which occurs in indurated sediments and may be a collapse sink over an underlying crack. The southermmost rock exposures occur $300 \mathrm{~m}$ south 
of the edge of the wall. Farther south the terrain is flattish, smooth, and sediment covered. It is possible, therefore, that the width of the transform fault zone is smalier (about $600 \mathrm{~m}$ ) in the region where a principal transform displacement zone exists.

No structures trending $045^{\circ}$ were ob. served south of the east-west scarp, where the distance from the $045^{\circ}$ trough is $4 \mathrm{~km}$. This may indicate that the $045^{\circ}$ transition structure which joins the accreting to the transform segment is not dynamically stable and represents a recent readjustment (less than $4 \times 10^{5}$ years old, assuming a spreading rate of $1 \mathrm{~cm} /$ year).

Rocks. Seven rock samples were collected during the three dives closest to the in tersection, that is, west of $33^{\circ} 10^{\prime} \mathrm{W}$. The predominant rock types are olivine basalts and moderately phyric plagioclase basalts. The specimens consist of large fragments of pillow lava with preserved glassy margins thinly coated by manganese and palagonite. One sample of pyroxene-enriched basalt with a subophitic texture was collected from the $045^{\circ}$ trending scarp, where banded rocks are exposed. This basalt is the most weathered of the eight specimens. Twelve rocks were sampled during the two dives east of $33^{\circ} 10^{\prime} \mathrm{W}$ (box III, Fig. 2) Most of the specimens taken from the major east-west escarpment consist of pyroxene basalt. The rocks are columnar with polygonal outlines and are holocrystalline with subophitic textures. The general appearance of the rocks, their textural features, and the geological settings suggest that they may be intrusives. Fresher rocks with preserved glassy margins, including one sample of ropy lava from the one emissive fissure observed, consist of moderately phyric plagioclase basalts similar in composition to those found in the inner floor and near the intersection.

Discussion. The Archimede dives in the intersection region between the rift and transform valleys showed that the transition from extensional to shear structures is gradual, with a set of intermediate directions; it includes a $\mathrm{l}-\mathrm{km}$-wide active trough oriented $045^{\circ}$, that is, in a direction inter mediate between the rift $\left(020^{\circ}\right)$ and transform $\left(090^{\circ}\right)$ directions. This situation probably reflects a mode of deformation of crustal material which is not linked in a simple way to the kinematics of the two purely rigid plates. Study of the transition area suggests that the zones in which mos of the deformation is occurring in the rift and transform valleys are 1 to $1.5 \mathrm{~km}$ wide and $1 \mathrm{~km}$ wide, respectively. The major east-west wall may represent a principal transform displacement zone composed of synthetic shears. In the region where the wall is better defined, the transform fault zone may be only $600 \mathrm{~m}$ wide. The rocks sampled on tectonic scarps are uniformly enriched in pyroxene and may be intrusives.

\section{Conclusions}

1) The key problem, determining the present surface expression of the plate boundary in a rift valley and a transform fault, can now be partly solved. In the rift valley, injection and accretion of crust are most intense in the $\mathrm{l}-\mathrm{km}$-wide axial zone of the inner floor, where there are young emissive centers such as Mont de Vénus, but also occur within at least $1 \mathrm{~km}$ on either side of the axial zone with a type structure of horsts and graben partly accompanied by volcanism. The greatest density of active tectonic features is found in the inner floor of the rift valley, but some active extension with little or no accompanying volcanism is maintained over an $8-\mathrm{km}$-wide zone. A structural setting in which the width of the injection and tectonic zones is similar is found in the Asa graben (19). Results of dives near the intersection of the rift valley and transform valley suggest that most of the accretion of lithosphere is accomplished within the 1to $1.5-\mathrm{km}$-wide axial zone of the inner floor. Precise dating of the basalts sampled in the inner floor would definitively show the pattern of accretion of new crust at this accreting plate boundary. A quantitative estimate of extension will be based on reconstruction of faults.

In the transform valley the presently active transform fault zone is about $1 \mathrm{~km}$ wide, but it may have migrated within the $3-\mathrm{km}$-wide transform domain. The major south-facing, east-west wall, on the north side of the deepest, part of the transform valley, may represent the principal transform displacement zone, but recent tectonic activity is not confined to it and may be spread over a distance of $600 \mathrm{~m}$.

2) The predicted left-lateral sense of shear motion in transform fault $A$ was verified in the field by observations on deformed sediments in the transform fault zone and by the existence of an emissive tension fracture striking $045^{\circ}$

3) Results of the dives indicate that commonly accepted concepts of the geology of transform faults need to be revised. The distribution of scarps within the transform valleys is such that the valleys do not necessarily provide a good section of the oceanic crust. Although the occurrence of uttramafics in transform faults is not explained by our data, we speculate that they may be linked to intrusions along deep vertical faults.

Sections of the uppermost part of the crust can be obtained on the steep, and often large, normal fault scarps that are found on the inward-facing walls of the rift valley. Systematic exploration of such large walls by submersibles may provide a less ambiguous magmatic stratigraphy of the upper part of the oceanic crust than near-vertical drill cores in crust where the density of faults, both synthetic and antithetic, may reach one every $50 \mathrm{~m}$.

4) Direct observations and sampling of hydrothermal emissive fissures and related metalliferous deposits were made in the transform fault zone. The deposits are mainly rich in iron and manganese and depleted in other transition elements. The iron is preferentially located close to the emissive vents.

\section{References and Notes}

1. X. Le Pichon, Recherche 5, 674 (1974); J. R Heirtzler and X. Le Pichon, Geslogy 2, 273 (1974). Sci Lell 22, 29 (1974)

Cheminée, J. Francheteau, R. ékintan, X. Le Pichon, H. D. Needham, R. D. Ballard, Nature (Lond 1 250, 558 (1974)

4. V Renard. B. Schrumpf, J. C. Sibuet, D. Carre, in Bathvmetrie detaillee d'une partie de vallée du
Rift et de faille Transformante pres de $36^{\circ} 50^{\prime}$ dans locean Alanituqu (Centre National pour l'Exploitation des Océans. Paris. 1975 )

5. J. (i. Moore, H.S. Fleming, J. D. Phillips, Geology 2,437 (1974).

6. Hékintan and M. Hoffert, Mar. Geol., 19, 9 (1975)

7. H. Bougault and R. Hékinian, Earth Planet. $S c$ Letl. 24.249 (1974).

R. C. Spindel, S. B. Davis, K. C. MacDonald, R.P. Porter, J. D. Phillips, Nature (Lond.) 248, 57 (1974)

9. F. Aumento, Can. J. Earth Sci. 5, I (1968): A Miyashiro, F. Shido, M. Ewing, Contrib. Mineral.
Petrol. 23, 38 (1969).

0. Scientific.

1. H. W. Menard, Geol. Soc. Am. Bull. 65, 1284 (1954)

J. T. Wilson, Nature (Lond 1207,343 (1965).

13. J. S. Tchalenko, Geol. Soc. Am. Bull. 81, 162 (1970): and N. N. Ambraseys, ibid., p. 4 D. Greenewalt and P. T. Taylor, J. Geophys. Res. 79,4401 (1974)

15. H. D. Hoiland and H. Bougault, personal communications

6. E. Bonatti, D. E. Fisher, O. Joensuu. H. S. Rydell. M. Beyth, Econ Geol 67, 717 (1972): E. Bonatti, J. Honnorez, O. Joensuu, H. Rydell, in The Mediterranean Sea: A Natural Sedimentation Labora tory, D. J. Stanley. Ed. (Dowden. Hutchinson Ross, Stroudshurg. Pa, 1972), p. 701.

17. R. S. Deirick, J. D. Mudic. B. P. Luyendyk. K. C MacDonald, Vat Phis Sti 246. 59 (1977); Reid and K. MacDonald, Nalure (Lond.) 246, 88
(1973).

8. Courtillot, P. Tappon
physics 24, 317 (1974).

19. H. D Needham, P. Choukroune J L Chemince X. Le Pichon. J. Francheteau, Geol Soc Am. Abstr Programs $686(1974)$

20. We thank C. C. de Froberville, L. V. Harismendy and $L$. V. de Guillebon for piloting Archimede and R. Kientzy and (G. Sciarrone for piloting Crana, all with great skill through very difficult terrain. W also thank the diving engineers J.F. Drogou, J Jarry, H. Leroux, J. L. Michel, and D. Semac and other personnel of the Base Oeeanologique du Mediterranee-Centre National pour l'Exploitation des Oceans for invaluable assistance. The of ficers and crew of Navy ship Marcel Le Bihan and research vessel Le Noroil showed great en thusiasm. The dives would not have been possible without the excellent base maps derived fice survey das of the French Hydrographic Orhee ship d Entrecasteaux under the leadership of and J.C Sibuet We thank C Riffaud . Renard the FAMOUS cial suppor from CNEXO. We thank $N$. Gullo and $Y$. Potard for editing the manuscript and $R$. Thirion for drafting the illustrations. $J$. Coulomb Thirion for drafting the illustrations. Al. Coulomb tists included in ARCYANA participated in the dives, except $P$. Tapponnier, who worked on shipboard interpretation. Contribution No. 336 of the Département Scientifique du Centre Océanologique de Bretagne, B.P. 337, 29273 Brest, France. 